\title{
Aspects of the Psychological Well-being of Muslim Students in Bandung from the Perspective of Islamic Psychology during the Covid-19 Pandemic
}

\author{
Ecep Supriatna ${ }^{1 *}$, Muhammad Rezza Septian ${ }^{2}$ \& Tuti Alawiyah ${ }^{3}$ \\ ${ }^{123}$ IKIP Siliwangi Bandung, Indonesia \\ *ecep83supriatna@gmail.com
}

\begin{abstract}
This article aims to explore aspects of the psychological well-being of Muslim students in Bandung during the Covid19 pandemic from the perspective of Islamic psychology. This study uses a quantitative approach with a survey method. The research participants consisted of 576 Muslim students in Bandung. Data were collected using a psychological well-being instrument developed by Ryff. The data analysis technique used is factor analysis. Based on the results of the study, it was obtained that the dominant aspects of psychological well being were ranked, namely positive relations with others at $74.1 \%$; second, purpose in life by $73.2 \%$; third, self-acceptance of $71.5 \%$; fourth, autonomy of $71.4 \%$; fifth, environmental mastery of $70.1 \%$ and the sixth, personal growth of $69.8 \%$.
\end{abstract}

Keywords: Psychological well-being; muslim students; covid-19.

\begin{abstract}
ABSTRAK
Artikel ini bertujuan untuk mengeksplorasi aspek-aspek kesejahteraan psikologis pada mahasiswa muslim di kota Bandung selama pandemi Covid19. Penelitian ini menggunakan pendekatan kuantitatif dengan metode survey. Partisipan penelitian terdiri dari 576 mahasiswa beragama Islam di kota Bandung dan Cimahi. Data dikumpulkan menggunakan instrumen kesejahteraan psikologis yang dikembangkan oleh Ryff. Teknik analisis data yang digunakan yaitu analisis faktor. Berdasarkan hasil penelitian diperoleh peringkat aspek-aspek yang dominan terhadap psychological well being yaitu: Pertama positive relations with others sebesar $74.1 \%$; Kedua, purpose in life sebesar 73.2\%; Ketiga, self-acceptance sebesar 71.5\%; Keempat, autonomy sebesar 71.4\%; Kelima, environmental mastery sebesar 70.1\%; dan Keenam, personal growth sebesar $69.8 \%$.
\end{abstract}

Kata kunci: Kesejahteraan psikologis; mahasiswa muslim; covid-19. 


\section{INTRODUCTION}

The World Health Organization (WHO) declared COVID-19 a global public health emergency of international concern (Cucinotta \& Vanelli, 2020). The COVID-19 pandemic has caused people's activities to no longer be the same as they used to be. to study from home. COVID-19 has a serious impact on students, instructors, and education around the world (Mailizar, et al., 2020). The pandemic has caused universities around the world to close campuses and students are required to implement health protocols (Toquero, 2020). Students are faced with change, related to obstacles and challenges in the current situation (Crawford, et al., 2020; Kaur, 2020). However, the move from conventional learning to distance or online learning requires adjustments that cannot be done in a short time. This adjustment ultimately has an impact on mental health and psychological disorders (Arnout, et al., 2020; Liebrenz, et al., 2020).

The majority of students object to online learning. Challenges faced by university students in developing countries, in this case Indonesia, include, among others, lack of access to internet facilities, lack of interaction and proper contact between students and lecturers and ineffective technology (Ahmad, 2020). The results of the study show other challenges faced by students such as lack of campus socialization, group study problems and reduced teaching time for lecturers, as well as social interaction among students in traditional classrooms. Students usually actively participate in academic activities because of face-to-face meetings with lecturers and classmates, while in online learning students not only have to know how to deal with online classes but must have good technology skills to learn from online lectures (Adnan, 2020).

The majority of student object that COVID-19 has created significant challenges for higher education institutions and a major disruption in the teaching and learning process. The results of the study by Dodd, et al. (2021) revealed that $86.8 \%$ of the 787 Australian students studied, they stated that COVID-19 had an impact on the study. College students have been identified as a "very high risk population" for mental health difficulties (Browne, et al., 2017). Studies conducted at Australian universities have revealed increased levels of general psychological distress and depressive symptoms. Studies in the United States and the United Kingdom reported similar findings (Prince, 2015).

Psychological stress impacts student learning, participation, and 
academic experience, so it is important for universities to understand and support their psychological well-being (Baik, Larcombe, \& Brooker, 2019). Students have experienced increased stress during the COVID-19 pandemic. Psychological well-being is an important topic in psychological research. Usually psychological well-being is conceptualized as some combination of positive affective such as happiness and optimal functioning in individual and social life (Deci \& Ryan, 2008).

In addition, psychological well-being refers to the degree to which individuals feel that they have meaningful control over their lives and activities. In the context of education, psychological well-being is an interesting topic of study related to the challenges faced during learning which are an inevitable part of students (Gallagher, 2009). online learning. Challenges faced by university students in developing countries, in this case Indonesia, include, among others, lack of access to internet facilities, lack of interaction and proper contact between students and lecturers and ineffective technology (Ahmad, 2020).

The results of the study show other challenges faced by students such as the lack of campus socialization, group study problems and reduced teaching time for lecturers, as well as social interaction among students in traditional classrooms. Students usually actively participate in academic activities because of face-to-face meetings with lecturers and classmates, while in online learning students not only have to know how to deal with online classes but must have good technology skills to learn from online lectures (Adnan, 2020).

In the context of religion, mental health is a very important aspect in creating a happy and prosperous human life, because a person's ability to think, act, evaluate himself, and make decisions in his life, is largely determined by his mental health (Arifin \& Satriah, 2018). Islam itself appreciates the importance of psychological well-being. The Qur'an can be used as a guide for those suffering from emotional distress and aims to lead people to a meaningful quality of life. "There is no disease that Allah has created, but He also created the cure" (Hadith).

Islam is a comprehensive way of life covering all aspects of life (individual, spiritual, economic, social, political, and family). Muslims believe that religious values cannot be separated from every aspect of life (Hamdan, 2007; Joshanloo, 2013; Pridmore \& Pasha, 2004). In practice, the application of Islamic psychology can take various forms, but its substance cannot be separated from the values of Islam itself. As it relates to 
psychological well-being.

Psychological well-being refers to a person's feelings about daily life activities where the process fluctuates (Ryff, 1989). Aspects of Psychological well-being consist of Autonomy, Environmental Mastery, Personal Growth, Positive Relations with Others, Purpose in Life, and SelfAcceptance. Self-Acceptance shows individuals who have shortcomings and failures in their lives, but they still accept these shortcomings and failures. Self-acceptance is the level of an individual's ability to act, be responsible and introspect. Positive Relations with Others is related to a relationship of mutual trust and warmth.

Individuals have caring, empathy and affection in interpersonal relationships. Autonomy is the ability of individuals to determine their own destiny, freedom, internal control and behavior. The characteristic of autonomy is being independent and able to make decisions without pressure from others. Environmental Mastery is the ability of individuals to choose or create an environment according to their wishes and needs. Purpose in Life includes what we want and will achieve in life, thus making life more meaningful. Personal Growth is the ability to develop the potential within himself and the level of individual ability to develop his potential continuously (Carol. Ryff \& Keyes, 1995).

Psychological well-being mer Autonomy, Environmental Mastery, Personal Growth, Positive Relations with Others, Purpose in Life, and SelfAcceptance. has a contribution in the formation of psychological well being in individuals. Regarding how pressure and workload affect a person's mental health and how these aspects of psychological well being contribute to maintaining a person's psychological health, there are at least some studies that examine this. The relationship between workload and psychological well-being was found to be different depending on whether the job yielded financial benefits to a person or not.

The level of self-acceptance and the level of personal growth are determinants of psychological well-being in workloads that do not mandate financial gain (Lindfors, Berntsson \& Lundberg, 2006). Goals in life and personal growth were found to contribute to career commitment (Strauser \& Lustig, 2008). Workload is associated with different roles with psychological well-being (Carr, 2002). For example, older women and younger men who adjust their work schedules to meet family demands have higher self-acceptance.

Participation in religious activities is associated with psychological 
well-being. In late adulthood, religiosity is positively associated with positive relationships with others, whereas spirituality is positively associated with personal growth (Wink \& Dillon, 2003). Participation in religious activities is associated with life goals and personal growth (Greenfield, Vaillant \& Marks, 2009). refers to a person's feelings about activities of daily living where the process fluctuates (Ryff, 1989). Psychological well-being aspects consist of Autonomy, Environmental Mastery, Personal Growth, Positive Relations with Others, Purpose in Life, and Self-Acceptance.

Self-Acceptance shows individuals who have shortcomings and failures in their lives, but they still accept these shortcomings and failures. Self-acceptance is the level of an individual's ability to act, be responsible and introspect. Positive Relations with Others is related to a relationship of mutual trust and warmth. Individuals have caring, empathy and affection in interpersonal relationships. Autonomy is the ability of individuals to determine their own destiny, freedom, internal control and behavior. The characteristic of autonomy is being independent and able to make decisions without pressure from others. Environmental Mastery is the ability of individuals to choose or create an environment according to their wishes and needs. Purpose in Life includes what we want and will achieve in life, thus making life more meaningful. Personal Growth is the ability to develop the potential within himself and the level of individual ability to develop his potential continuously (Ryff \& Keyes, 1995).

Based on the previous description, Psychological well-being has an important role for students, especially in dealing with psychological pressure on online learning in the COVID-19 pandemic situation. At least there are several reasons why this research is important. First, from the research conducted, there are no or very few studies that discuss how psychological well-being is viewed from the aspects that most influence or contribute to psychological well-being, especially for students in dealing with the pressures of online learning during the COVID-19 pandemic.

Second, besides that, the student age is a young adult age where a person is faced with challenges and difficulties that might make them experience confusion and difficulty. However, at this age is also a period in which the individual can be prepared for future adult life. Understanding the well-being of young adults and the aspects that contribute to it will help clarify and define ways to help prepare for their lives better (Roothman, Kirsten \& Wissing, 2003). Third, most of the empirical research spread 
among Muslims uses large sample sizes that are not representative of the Islamic population itself. The application of psychological theories and conceptual frameworks that have been developed mainly in the context of Western culture to Islam may be biased and fail to capture the uniqueness of religion, and may be culturally insensitive (Abu-Raiya, et al., 2007; Amer, et al., 2008; Ghorbani, Watson \& Reza, 2007). So that this study specifically took research participants who were Muslim.

This research is a quantitative approach research with survey method. Survey is a procedure in quantitative research where the researcher administers a survey on a sample or on an entire population of people to describe attitudes, opinions, behaviors or specific characteristics of the population (Cresswell, 2018). The participants of this research are Muslim students who come from campuses such as the State Islamic University of Sunan Gunung Djati Bandung, the Indonesian Education University, General Ahmad Yani University, and IKIP Siliwangi. The number of participants in this study were 576 students obtained from data collection by random sampling.

This study uses factor analysis, which is a technique used to find factors that can explain the relationship or correlation between various independent indicators in this case psychological well-being. Collecting data using a psychological well-being scale research instrument consisting of 18 statement items. In the research instrument there are aspects of The Autonomy, The Environmental Mastery, The Personal Growth, The Positive Relations with Others, The Purpose in Life, and The SelfAcceptance.

\section{RESULT AND DISCUSSION}

\section{Measure of Sampling Adequacy (MSA)}

Measure of sampling adequacy (MSA) is used to determine whether the variables are adequate for further analysis. This value can be seen in the anti-image correlation matrix value. If the MSA value is greater than 0.5 then the variable is sufficient for further analysis. If there are MSA values of the initial variables that are less than 0.5 , they must be removed one by one from the analysis, sorted from the variable with the smallest MSA value and not used again in the subsequent analysis.

Based on the results of data processing, the MSA results, on the antiimage correlation matrix value, are obtained as follows: 
Table.1 Test of Measure Of Sampling Adequacy (MSA)

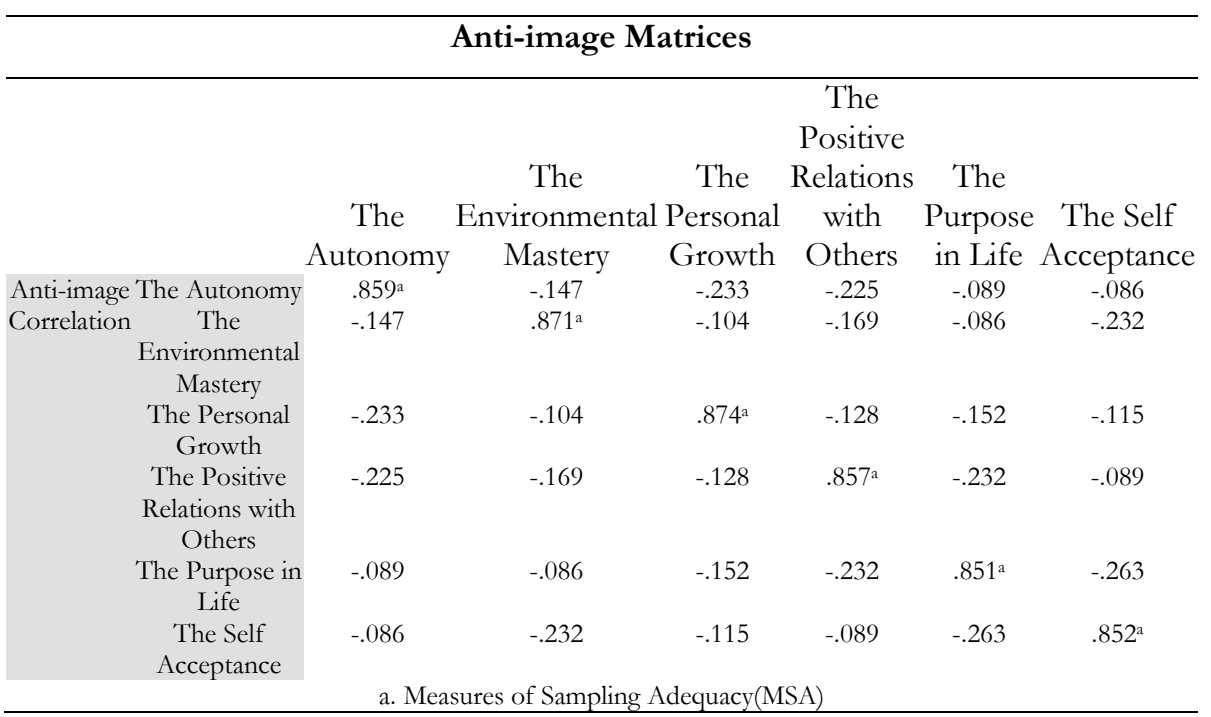

Source: Data Processing Results, 2021

Based on the table 1 above, the results of the measure of sampling adequacy (MSA) test, it is obtained that the six factors of psychological well-being have an MSA value of $>0.5$, so it can be stated that all aspects/factors can be predicted and tested by further analysis.

\section{KMO and Barlett Test (Measure of Sampling Adequacy)}

Testing the adequacy of the sample through the Kaiser-Meyer-Olkin (KMO) measure of sampling adequacy and the significance value of Bartlett's test of sphericity. This index is used to examine the accuracy of the use of factor analysis. If the KMO value is between 0.5 and 1 and the significance of Bartlett's test of sphericity is less than the significance level $(\alpha)$ used, it means that factor analysis is appropriate. Based on the results of data processing, the test results obtained, as follows:

Table. 2 Test of KMO dan Barlett Test

\begin{tabular}{ccc}
\hline \multicolumn{3}{c}{ KMO and Bartlett's Test } \\
\hline Kaiser-Meyer-Olkin Measure of Sampling Adequacy. & .860 \\
Bartlett's Test of Sphericity & Approx. Chi-Square & 924.988 \\
& Df & 15 \\
& Sig. & .000 \\
\hline
\end{tabular}

Source: Data Processing Results, 2021 
Based on the table above, the results of testing the adequacy of the sample through the Kaiser-Meyer-Olkin (KMO) measure of sampling adequacy and the significance value (pvalue) of Bartlett's test of sphericity, obtained the KMO result of $0.860(0.860>0.5)$ with a significance ( $\mathrm{p}$-value) of Bartlett's test. of sphericity of $0.000(0.000<0.05)$, so it can be concluded that factor analysis is appropriate to use to simplify the collection of several of these factors.

\section{Analysis of Total Variance Explained}

The following is a table of the total variance explained test results from this study, which are as follows:

Table. 3 Total Variance Explained

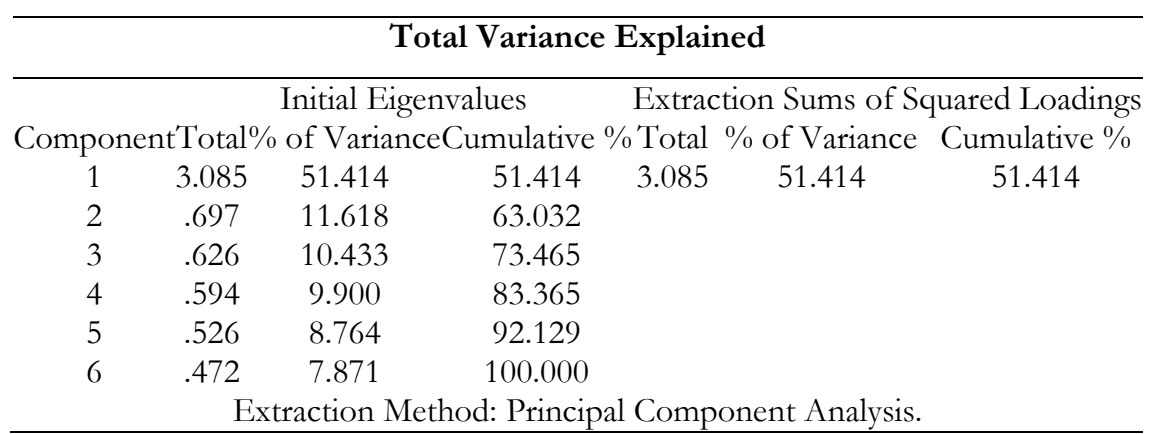

Source: Data Processing Results, 2021

Based on the table above, to determine the factors formed. Then it must be seen that the eigenvalues must be above one (1). If it is below one (1), then there are no formed factors, from the table above we can see that there is 1 forming factor. The number of factors in this factor analysis is determined based on the cumulative proportion value. If the cumulative proportion value ranges from $50 \%-60 \%$, then the component can be selected as the main component or factor. The forming factors with cumulative proportions ranging from $50 \%-60 \%$, in this study, were able to explain $51.41 \%$, of the total diversity of the dimensions in the study.

\section{Component Matrix}

After knowing the formed factors, the next step is to determine the dominant items in each of these components. This can be seen from the component matrix table which shows the distribution of the 1 factor research items formed. component matrix consists of initial items to the formed factors. By looking at the weighting factor, it can be determined 
which item belongs to which factor. By looking at the weighting factor for each item formed, based on the results of data processing, the results of the matrix components are obtained as follows:

Table. 4 Component Matrix

\begin{tabular}{cc}
\hline \multicolumn{2}{c}{ Component Matrix $^{\mathbf{a}}$} \\
\hline & Component \\
The Autonomy & 1 \\
The Environmental Mastery & .714 \\
The Personal Growth & .701 \\
The Positive Relations with Others & .698 \\
& .741 \\
The Purpose in Life & .732 \\
The Self Acceptance & .715 \\
Extraction Method: Principal Component Analysis. \\
a. 1 components extracted. \\
\hline
\end{tabular}

Source: Data Processing Results, 2021

Based on the table 4 above, it can be concluded that psychological well being factors come from 1 component factor and the most dominant factor is the positive relations with others factor of $74.1 \%$, the next is the purpose in life of $73.2 \%$, the self acceptance is $71.5 \%$, the autonomy is $71.4 \%$, the environmental mastery is $70.1 \%$ and finally the personal growth is $69.8 \%$.

Based on the results of the study, there are three aspects that have the highest level of influence on Psychological well being, namely the positive relations with others, the purpose in life, and the self-acceptance. This discussion focuses on these three aspects. There is evidence of the importance of a positive relationship that is correlated with the experience of positive emotions (Böckmann, 2019).

The impact of the positive relations with others is that individuals are able to build and maintain social relationships and access social support who are described as tough individuals so that they have an important role for students in dealing with academic pressure during the Covid 19 pandemic. Higher positive relationship scores were positively associated with all strategies and mastery goal orientations (Ness et al., 2015). The results of this study support the socio-cognitive view that positive relationships with others are important factors associated with the use of 
self-regulatory strategies and academic motivation.

The positive relations with others itself is the level of ability in warm relationships with others, interpersonal relationships based on trust, strong feelings of empathy, and affection. Allah himself, as created humans as social beings as stated in the QS. al-Hujurat verse: 13. The stronger the recognition of one party to the other, the more open the opportunity for mutual benefit. Therefore, the above verse emphasizes the need to know each other. The introduction is needed to draw lessons from each other and the experiences of the other party, the impact of which is reflected in the peace and prosperity of life in this world and the happiness of the hereafter. A further stage of getting to know each other in positive relationships with others is doing good. Good deeds in addition to improving relationships with others are also God's orders and will also get better rewards as stated in QS Al Baqarah verse 58 and QS Al-Maidah verse 13.

The goal of the positive relations with others is to help individuals create and promote strong relationships with themselves and others by encouraging social and emotional skills. Social relationships have also been found to be important predictors of psychological well being (Myers, 2000) and meaning in life (Hicks \& King, 2009; Lambert, 2010). Positive relations with others are believed to foster good health with positive emotions that have a beneficial impact on body systems (Cohen, 2004). Overall, feeling connected to others is believed to play a key role in good physical and mental health throughout life. One of the reasons that positive relations with others are consistently associated with mental and physical health is that humans are believed to have basic biological and psychological needs for social interaction and connectedness (Baumeister, \& Leary, 1995).

According to Deci \& Ryan (2008) that individuals have a deep need to feel secure in their relationships with others and consider themselves worthy of being loved, loved and respected. Humans experience a strong need to feel secure in emotional attachment to others (Kennedy \& Kennedy, 2004). Besides being beneficial for psychological well-being, research shows that positive relations with others have benefits for academic achievement. Individuals with strong and supportive peer relationships have been shown to perform better academically than those without such support (Wentzel \& Caldwell, 1997; Wentzel, 1991).

Having a purpose of life is fundamental and has an impact on all areas of life (Schippers, 2017). Research shows that purpose of life supports 
and is associated with increased levels of overall well-being (Bonebright, Clay \& Ankenmann, 2000), global happiness (Debats, Van der Lubbe \& Wezeman, 1993; Ryff \& Keyes, 1995), life satisfaction (Steger \& Oishi, 2009), and a lack of purpose in life are associated with various psychological disorders (Heisel \& Flett, 2004). Ryff (1989) understands the purpose of life as a purpose, intention, and sense of direction in life that combine to produce a feeling that one's life is meaningful, and act to integrate various aspects of one's life into a comprehensive whole. If it is associated with the psychological pressures of online learning faced by students during the Covid19 pandemic, the purpose of life has an important contribution to the resilience of students in dealing with these various pressures.

Humans are not just created without a purpose in life. The main purpose of humans created by Allah SWT is to be able to worship Allah SWT as stated in Qs Adz Zariyat verse 56. The worship that can be carried out by humans to fulfill their duties as servants of Allah can be general or specific. Worship that is special is worship that is directly addressed to Allah SWT such as prayer, reading the Koran etc. The worship that is carried out in general is worship that is related to human relations with each other such as connecting ties of friendship and helping each other. As creatures who are endowed with reason, humans have an obligation to manage natural resources and maintain their sustainability. Not only that, humans are also obliged to protect themselves from bad behavior because every human treatment or action in the world will be held accountable. In accordance with the word of Allah SWT in the letter Al-Baqarah verse 30

The purpose of life has far-reaching consequences for individual happiness and performance but also for the well-being and happiness of those around them (Ryan \& Deci, 2001). purpose of life is related to positive feelings of mental and physical health and is a predictor of psychological well-being (Reker, Peacock \& Wong, 1987). While there are many plausible explanations for why a purpose of life can provide such benefits, it is interesting to explore three possible reasons in detail: goals can 1. meet basic human needs, 2. influence one's prospects in a positive direction, and 3. each. constitutive elements of well-being. Not everyone has a purpose of life (Keyes, 2011; Rockind, 2011; Steger, et al., 2008).

Regarding student academic activities during Covid19, individuals who are very curious and open to new experiences are more likely to seek and live out their purpose of life (Kashdan \& McKnight, 2009). Curiosity increases one's sense of meaning in life (Kashdan \& Steger, 2007). the 
purpose of life depends also on age. Based on the theory of human development, it seems that one's purpose of life continues to increase with age so that it is at a point of stability.

Steger, Oishi, \& Kashdan (2009) found that the developmental stage generally experiences more meaning in life than the previous stage of development. Ryff \& Keyes (1995) found that older individuals have a more purposeful life purpose. Other studies have also shown that the purpose of life is related to educational attainment. Ryff, Keyes \& Hughes (2003) show that more educated individuals have more purposeful life goals. Thus, directing individuals to have a purpose of life seems to be the right way to help others have a better and healthier life (Menec, 2003; Seligman, et al., 2005), especially for college students facing the Covid19 pandemic.

The third order aspect that has an influence on psychological well being is self-acceptance. Wood, Joseph \& Maltby (2009) revealed that selfacceptance is able to predict the presence of gratitude. Hurlock (2009) says that individuals who like themselves will be able to accept themselves and be increasingly accepted by others, in other words individuals with good self-acceptance will be able to lead to positive emotions, namely gratitude. During the Covid19 pandemic, students need to have self-acceptance, especially with regard to the conditions faced during this pandemic, including various changes and adjustments that are a special pressure for students. Research (Bingöl \& Batık, 2018) shows that self-acceptance is one of the predictors of psychological well being. This acceptance philosophy means acknowledging that everything that exists exists but does not have to exist forever (Dryden, David \& Ellis, 2010).

Self-acceptance can be described with the word self-surrender. Surrender that we have tried our best and have prayed, then leave the results to God. We try to be sure, that all God's decrees must be the best. Both favors and disasters that befall can be used as an experience that can trigger their motivation to become better and not repeat mistakes that have passed in the past. Because humans who have self-acceptance are individuals who are able to accept themselves as they are and their experiences. With selfacceptance, it is possible for individuals to have a positive attitude towards themselves. With positive self-acceptance, tolerance for frustration and unpleasant experiences will increase. And Confident that Allah will never burden someone beyond the limits of his ability as stated in the QS. AlBaqarah verse 286. 
Self-acceptance refers to an individual's satisfaction with himself and is considered necessary for good mental health (Rogers, 1961; Scott, 1968). Self-acceptance requires a realistic and subjective awareness of one's own strengths and weaknesses. Unconditional self-acceptance involves selfacceptance without regard to the love, respect, and approval of others (Hill, Hall, Appleton \& Kozub, 2008). Unconditional acceptance can be stated if the individual accepts himself even when behaving in the wrong way). or unsuccessful. There is no need to evaluate or judge oneself or others as a whole positively or negatively. For example, a person's failure to complete a job does not make him an unsuccessful individual (Neenan \& Dryden, 2005). Self-acceptance and positive relationships can reduce depression (Edmondson \& Macleod, 2015). There is a relationship between a positive relationship and positive emotions and there is also evidence for the assumption that at least a moderate degree of positive relationship is necessary for it to thrive. This can be useful for individuals' daily lives (Böckmann, 2019).

\section{CONCLUSION}

The results showed that aspects of positive relations with others, purpose in life, and the self-acceptance had the highest level of influence on Psychological well being. First, positive relations with others, namely individuals are able to build and maintain social relationships and access social support so that they have an important role for students in dealing with academic stress during the Covid 19 pandemic. Social relationships have been found to be an important predictor of psychological well being. Positive relations with others are related to psychological well-being because humans have a psychological need for social interaction and connectedness. Individuals have a deep need to feel secure in their relationships with others.

Second, the Purpose of life is related to the feeling of someone's life being meaningful, this can help students to survive the pressures faced during the Covid19 pandemic. There are several things that support individuals to have a Purpose of life, namely curiosity, age, and education. third, self-acceptance is able to predict the existence of gratitude. Through self-acceptance, it is able to direct individuals to positive emotions which can help in this case students to have adequate psychological well being even though they are faced with difficult situations during the Covid19 
pandemic. self acceptance is one of the predictors of psychological well being.

\section{REFERENCE}

Abu-Raiya, H., Pargament, K.I., Stein, C., \& Mahoney, A. (2007). Lessons learned and challenges faced in developing the Psychological Measure of Islamic Religiousness, Journal of Muslim Mental Health, 2((2)), 133-154.

Adnan, M. \& K. A. (2020). Online learning amid the COVID-19 pandemic: Students' perspectives, Journal of Pedagogical Sociology and Psychology, 2(1), 45-51.

Ahmad, I. (2020). Fata and the internet.

Amer, M.M., Hovey, J.D., Fox, C.M., \& Rezcallah, A. (2008). Initial development of the Brief Arab Religious Coping Scale (BARCS), Journal of Muslim Mental Health, 3, 69-88.

Arifin, I. Z., \& Satriah, L.-. (2018). Model Dakwah bi al-Irsyãd untuk Pemeliharaan Kesehatan Mental Spiritual Pasien di Rumah Sakit, Ilmu Dakwah: Academic Journal for Homiletic Studies, 12(1), 99-120. https://doi.org/10.15575/idajhs.v12i1.1908

Arnout, B. A., Al-Dabbagh, Z. S., Al Eid, N. A., Al Eid, M. A., AlMusaibeh, S. S., Al-Miqtiq, M. N., Alamri, A. S., \& Al-Zeyad, G. M. (2020). The effects of corona virus (COVID-19) outbreak on the individuals' mental health and on the decision makers: A comparative epidemiological study, Health Sciences, 9(3), 26-47.

Baik, C. Larcombe, W. \& Brooker, A. (2019). How universities can enhance student mental wellbeing: The student perspective, High. Educ. Res, 38, 674-687.

Baumeister, R. F., \& Leary, M. R. (1995). The need to belong: Desire for interpersonal attachments as a fundamental human motivation, Psychological Bulletin, 117, 497-529.

Bingöl, T. Y., \& Batık, M. V. (2018). Unconditional Self-Acceptance and Perfectionistic Cognitions as Predictors of Psychological Well-Being, Journal of Education and Training Studies, 7(1), 67. https://doi.org/10.11114/jets.v7i1.3712

Böckmann, L. (2019). The Importance of Positive Relations in the Context of positive Emotions and Flourishing (pp. 1-29). http://essay.utwente.nl/78786/

Bonebright, C. A., Clay, D. L., \& Ankenmann, R. D. (2000). The Relationship of Workaholism with Work-Life Conflict, Life 
Satisfaction, and Purpose in Life, Journal of Counseling Psychology, 47, 469-477.

Browne, V.; Munro, J.; Cass, J. (2017). Under the Radar: The Mental Health of Australian University Students, J. Aust. New Zealand Stud. Serv. Assoc, 25, 51-62.

Cohen, S. (2004). Social relationships and health, American Psychologist, 59, 676.

Crawford, J., Butler-Henderson, K., Rudolph, J., \& Glowatz, M. (2020). COVID-19: 20 countries' higher education intra-period digital pedagogy responses, Journal of Applied Teaching and Learning (JALT), $3(1)$.

Cresswell, J. (2018). Educational Research: Planning, Conducting, and Evaluating Quantitative and Qualitative Research, 6th Edition. Pearson Education, Inc.

Cucinotta, D., \& Vanelli, M. (2020). WHO declares COVID-19 a pandemic, Acta Bio-Medica: Atenei Parmensis, 91(1), 157-16.

Carr, D. (2002). The psychological consequences of work-family tradeoffs for three cohorts of men and women, Soc Psychol Q, 65, 103-124.

Debats, D. L., Van der Lubbe, P. M., \& Wezeman, F. R. (1993). Debats, D. L., Van der On the psychometric properties of the Life Regard Index (LRI): A measure of meaningful life: An evaluation in three independent samples based on the Dutch version, Personality and Individual Differences, 14(2), 337-345.

Deci, E. L., \& Ryan, R. M. (2008). Hedonia, eudaimonia, dan kesejahteraan: Pengantar, Jurnal Studi Kebahagiaan, 9, 1-11.

Dodd, H Rachael, Dadaczynski, Kevin \& Okan, O. (2021). Psychological Wellbeing and Academic Experience of University Students in Australia during COVID-19, International Journal of Environmental Research and Public Health, 18(3), 866.

Dryden, W., David, D., \& Ellis, A. (2010). Rational emotive behavior therapy. In Handbook of cognitive behavioral therapies (pp. 226-276). The Guilford Press.

Edmondson, O. J. H., \& Macleod, A. K. (2015). Psychological Well-Being and Anticipated Positive Personal Events: Their Relationship to Depression, Clinical Psychology and Psychotherapy, 22(5), 418-425. https://doi.org/10.1002/cpp.1911

Gallagher, R. P. (2009). Survei Nasional Direktur Counelling Centre 2008. www.dscholarship.pitt.edu/28169/. 
Ghorbani, N., Watson, P.J., \& Reza, R. (2007). Relationship of selfreported mysticism with depression and anxiety in Iranian Muslims, Psychological Reports, 100(2), 451-454.

Greenfield EA, Vaillant GE, M. N. (2009). Do formal religious participation and spiritual perceptions have independent linkages with diverse dimensions of psychological well_being, $J$ Health Soc Behav, 50, 196-212.

Hamdan, A. (2007). A case study of a Muslim Client: Incorporating religious beliefs and practices, Journal of Multicultural Counseling and Development, 35(2), 92-100.

Heisel, M. J., \& Flett, G. L. (2004). Purpose in Life, Satisfaction With Life, and Suicide Ideation in a Clinical Sample, Journal of Psychopathology and Behavioral Assessment, 26(2), 127-135.

Hicks, J. A., \& King, L. A. (2009). Positive mood and social relatedness as information about meaning in life, Journal of Positive Psychology, 4, 471482.

Hill, A. P., Hall, H. K., Appleton, P. R., \& Kozub, S. A. (2008). Perfectionism and burnout in junior elite soccer players: The mediating influence of unconditional self-acceptance, Psychology of Sport and Exercise, 9, 630-644.

Hurlock, E. B. (2009). Psikologis Perkembangan: Suatu Pendekatan Sepanjang Rentang Kebidupan. Jakarta: Erlangga.

Joshanloo, M. (2013). Mental well-being in Iran: The importance of comprehensive well-being in understanding the linkages of personality and values. In C. L. Keyes (Ed.), Mental well-being: International contributions to the study of subjective well-being and positive. Springer International Publishing.

Kashdan, T. B., \& McKnight, P. E. (2009). Origins of purpose in life: Refining our understanding of a life well lived, Psychological Topics, 18 , 303-316.

Kashdan, T. B., \& Steger, M. F. (2007). Curiosity and pathways to wellbeing and meaning in life: Traits, states, and everyday behaviors, Motivation and Emotion, 31, 159-173.

Kaur, G. (2020). Digital Life: Boon or bane in teaching sector on COVID19, CLIO an Annual Interdisciplinary Journal of History, 6(6), 416-427.

Kennedy, J. H., \& Kennedy, C. E. (2004). Attachment theory: Implications for school psychology, Psychology in the Schools, 4, 247-259.

Keyes, C. L. M. (2011). Authentic purpose: The spiritual infrastructure of life, Journal of Management, Spirituality \& Religion, 8(4), 281-297. 
Lambert, N. M., et al. (2010). Family as a salient source of meaning in young adulthood, Journal of Positive Psychology, 5, 367-376.

Liebrenz, M., Bhugra, D., Buadze, A., \& Schleifer, R. (2020). Caring for persons in detention suffering with mental illness during the Covid19 outbreak, Forensic Science International: Mind and Law, 1(1).

Lindfors P, Berntsson L, L. U. (2006). Total workload as related to psychological well_being and symptoms in full-time employed female and male white-collar workers, Int J Behav Med, 13, 131-137.

Mailizar, Almanthari, A., Maulina, S., \& Bruce, S. (2020). Secondary school mathematics teachers' views on e-learning implementation barriers during the Covid-19 pandemic: The case of Indonesia, Eurasia Journal of Mathematics, Science and Technology Education, 16(7), 1860.

Menec, V. H. (2003). The relation between everyday activities and successful aging: A 6-year longitudinal study, The Journals of Gerontology: Series B: Psychological Sciences and Social Sciences, $58((2)), \mathrm{S} 74$ S82.

Myers, D. G. (2000). The funds, friends, and faith of happy people, American Psychologist, 55, 56-67.

Neenan, M. M., \& Dryden, W. (2005). Rational emotive behaviour therapy in a nutshell. https://0-ebookcetral-proquestcom.seyhan.library.boun.edu.tr/lib/bogazici-ebooks/detail. action?docID $=334511$

Ness, B. M., Middleton, M. J., \& Hildebrandt, M. J. (2015). Examining the Effects of Self-reported Posttraumatic Stress Disorder Symptoms and Positive Relations with Others on Self-regulated Learning for Student Service Members/Veterans, Journal of American College Health, 63(7), 448-458. https://doi.org/10.1080/07448481.2014.975719

Pridmore, S., \& Pasha, M. I. (2004). Psychiatry and Islam, Australasian Psychiatry, 12(4), 380.

Prince, J. . (2015). University student counseling and mental health in the United States: Trends and challenges, Ment. Heal. Prev, 3, 5-10.

Reker, G.T., Peacock, J.E., \& Wong, T. P. (1987). 1987-Reker-PeacockWong-Meaning-across-the-life-span.pdf, Journal of Gerontology (Vol. 42, Issue 1, pp. 44-49).

Rockind, C. L. (2011). Living on purpose: Why purpose matters and how to find it. The University of Pennsylvania.

Rogers, C. R. (1961). Client-centered therapy; its current practice, implications, and theory. Houghton Mifflin. 
Roothman, B., Kirsten, D. K., \& Wissing, M. P. (2003). Gender differences in aspects of psychological well-being, South African Journal of Psychology, 33((4)), 212-218.

Ryan, R. M., \& Deci, E. L. (2001). On happiness and human potentials: A review of research on hedonic and eudaimonic well-being, Annual Review of Psychology, 52, 141-166.

Ryff, C. D., Keyes, C. L. M., \& Hughes, D. L. (2003). Status Inequalities, Perceived Discrimination, and Eudaimonic Well-being: Do the Challenges of Minority Life Hone Purpose and Growth? Journal of Health and Social Behavior, 44((3)), 275-291.

Ryff, C. D. (1989). Happiness is everything, or is it? Explorations on the meaning of psychological well-being, Journal of Personality and Social Psycholog, 57, 1069-1081.

Ryff, Carol D., \& Keyes, C. L. M. (1995). The Structure of Psychological Well-Being Revisited, Journal of Personality and Social Psychology, 69(4), 719-727. https://doi.org/10.1037/0022-3514.69.4.719

Schippers, M. C. (2017). IKIGAI: reflection on life goals optimizes performance and happiness, ERIM Inaugural Address Series Research in Management.

Scott, W. A. (1968). Conceptions of normality. In Handbook of personality theory and research. Rand Mcnally.

Seligman, M. E. P., Steen, T. A., Park, N., \& Peterson, C. (2005). Positive Psychology Progress: Empirical Validation of Interventions, American Psychologist, 60((5)), 410-421.

Steger, M. F., Kashdan, T. B., Sullivan, B. A, \& Lorentz, D. (2008). Understanding the search for meaning in life: Personality, cognitive style, and the dynamic between seeking and experiencing meaning, Journal of Personality, 76((2)), 199-228.

Steger, M. F., Oishi, S., \& Kashdan, T. B. (2009). Meaning in life across the life span: Levels The, and correlates of meaning in life from emerging adulthood to older adulthood, Journal of Positive Psychology, 4((1)), 4352.

Steger, Oishi, \& K. (2009). Meaning in life across the life span: Levels and correlates of meaning in life from emerging adulthood to older adulthood, The Journal of Positive Psychology, 4((1)), 43-52.

Strauser DR, Lustig DC, C.. A. (2008). Psychological well-being: its relation to work personality, vocational identity, and career thoughts, J Psychol, $142,21-35$. 
Toquero, C. M. (2020). Challenges and opportunities for higher education amid the COVID-19 pandemic: The Philippine context, Pedagogical Research, 5(4).

Wentzel, K. R., \& Caldwell, K. (1997). Friendships, peer acceptance, and group membership: Relations to academic achievement in middle school, Child Development, 68((6)), 1198-1209.

Wentzel, K. R. (1991). Relations between social competence and academic achievement in early adolescence, Child Development, 62((5)), 10661078.

Wink P, Dillon, M. (2003). Religiousness, spirituality, and psychosocial functioning in late adulthood: findings from a longitudinal study, Psychol Aging, 18, 916-924.

Wood, A. M., Joseph, S., \& Maltby, J. (2009). Gratitude Predicts Psychological Well-Being Above The Big Five Facets, Journal of Personality and Individual Different., 46(10), 443-447. 
